Expósito, A., \& Berbel, J. (2019). Drivers of irrigation water productivity and basin closure process: Analysis of the Guadalquivir river basin (Spain). Water Resources Management, 33(4), 1439-1450.

\title{
Drivers of irrigation water productivity and basin closure process: Analysis of the Guadalquivir river basin (Spain)
}

\author{
Alfonso Expósito ${ }^{* *}$ and Julio Berbel ${ }^{2}$ \\ ${ }^{1}$ Department of Economic Analysis, University of Seville, 41018 Seville, Spain; \\ aexposito@us.es \\ 2 Department of Agricultural Economics, University of Cordoba, 14014 Cordoba, \\ Spain; berbel@uco.es \\ * Correspondence: aexposito@us.es; Tel.: +34 955420122
}

Acknowledgements: This research was financed by the Spanish Ministry of Economy and Competitiveness (MINECO AGL2014-53417-R). A previous shorter version of the paper was presented at the $10^{\text {th }}$ World Congress of EWRA "Panta Rei" Athens, Greece, 5-9 July 2017.

\begin{abstract}
This paper proposes a methodology for the analysis of the evolution of irrigation water productivity that enables the decomposition of its driving factors. The method is applied to the Guadalquivir river basin (southern Spain) in the period 1989-2012 where water policy has aimed to achieve greater irrigation efficiency (IE), defined as the ratio of water beneficially used divided by the total water applied, through the implementation of water conservation and saving technologies (WCSTs). The case study illustrates the basin closure process observed in recent decades and analyses its practical implications for irrigation water productivity and the role played by alternative responses, such as intensification and technical change. The analysis of these drivers of irrigation water productivity may help in the design of water policy in water-scarce areas elsewhere.
\end{abstract}

Key words: irrigation water productivity, river basin closure, technical change, agricultural water management. 


\section{Introduction.}

The growing agricultural demand for water along with increasing pressure from alternative uses in a context of increasing water scarcity exacerbated by climate change represent significant global challenges, especially in those river basins (or regions) characterised by a limited supply capacity. This mismatch between supply and demand leads to the total depletion of available water resources, a situation which characterises a 'closure' status on a river basin scale (Falkenmark and Molden 2008; Molle et al. 2010). Basin closure typically occurs when a high level of efficiency in the use of the resource has already been achieved and all available resources are depleted by the alternative uses on a river basin scale. In this context, the efficient use of irrigation water, understood as the capacity to generate the maximum economic value per irrigation unit, has become an increasingly important aspect of water management worldwide, especially in water-stressed areas, such as the Mediterranean region (EC 2012; EEA 2009).

This study uses the concept of irrigation water productivity, measured in terms of gross value added (GVA) per cubic metre of irrigation water used, as an indicator of the river basin capability to generate economic wealth per irrigation unit. The productivity is decomposed into partial indicators of water-use intensity and land productivity to assess the dynamic evolution of irrigation water productivity in the context of river basin closure, technological change, and policy responses to water scarcity (Molle et al., 2010). The case study focuses on the Guadalquivir river basin (GRB) where investment in water conservation and saving technologies (WCSTs) has been the main public and private policy response to basin closure with the goal of achieving higher irrigation water-use efficiency. This has played a major role in explaining the evolution of irrigation water productivity over the last two decades (Lopez-Gunn et al. 2012, Expósito and Berbel 2017a). Irrigation water productivity has been affected mainly by three factors on the basin scale: 1) increased IE due to intense implementation of WCSTs; 2) expansion of area irrigated; and 3) changes in the crop mix through an increase in the share of higher-value crops. This paper aims to assess the role played by these factors on the dynamics of irrigation water productivity in the GRB for the period 1989-2012.

The rest of this paper is organised as follows: the following section introduces the theoretical framework regarding the process of river basin closure (or on a larger scale, the maturing of the water economy). The GRB case study and the proposed analytical framework is then described in the third section, while the fourth section outlines the estimated evolution of the irrigation water productivity and its main drivers in the GRB. Finally, this work ends with a discussion section and concluding remarks. 


\section{Irrigation water productivity and the process of river basin closure.}

According to production theory, productivity is defined as the ratio between agricultural yield and the volume of water used; this approach remains the most widely applied to water management. Initially proposed by Doorenbos and Kassam (1979), studies, such as those by Perry (2011) and Klein et al. (2012), conclude that output values per unit of irrigation water are good proxies for the assessment of irrigation water productivity, while Steduto et al. (2012) review the coefficients that determine yield response to water supply. From a physical perspective, water productivity is defined as the crop output per unit of water used (often expressed in $\mathrm{kg} / \mathrm{m}^{3}$ ), while from an economic perspective, irrigation water productivity is defined as the monetary value derived per unit of water used (i.e., $\left.\mathrm{EUR} / \mathrm{m}^{3}\right)$. Therefore, in economic terms, an improvement in water productivity would mean producing more value with less water.

Irrigation water productivity is affected by many different factors within the river basin, including technical, agronomic, and environmental drivers (Berbel et al. 2013; Molle et al. 2007). The process by which a river basin reaches 'closure' status is also multidimensional (Molle et al. 2010), illustrating the change from a state of abundant resources to one of scarcity, or a mature water economy where available water resources are depleted. Randall (1981) defines a 'mature phase' characterised by: (1) no expectation of significant supply increases, resulting in an inelastic water supply with increasing marginal supply costs; (2) high and growing demand for the resource with increasing conflicts among competing users; and (3) a rise in undesirable social and environmental externalities. This framework describes the maturing state of a national or basin water economy in economic terms. Authors from hydrology and agronomy use the concept of 'basin closure' to describe an anthropogenic process that leads to a total allocation of water resources among alternative uses on a river basin scale (Molle et al. 2010). The 'basin closure' framework has been used by various studies, such as those by Comair et al. (2013) and Berbel et al. (2013). Both frameworks describe similar processes but viewed from two alternative perspectives although the latter pays closer attention to agronomic drivers (e.g., farmers' decisions on crop mix) than does the approach by Randall. In fact, both frameworks assume that farmers are pressed to make decisions involving changes in the way they use irrigation water, which affect irrigation water productivity through the aforementioned main drivers: higher IE (implementation of WCSTs), and maximization of the economic value generated per irrigation unit (i.e., changes in the crop mix). The increase in irrigation water productivity leads to pressures involving a growing demand for water resources. When supply cannot be further increased, overexploitation of the resource leads to a total depletion of available resources. At this stage, demand control and re-allocation become the only way to reduce pressure on the resource and is typical of a closed river basin (and on a larger scale, of a water mature economy). 
This work presents a methodology to decompose productivity evolution applied to the case of GRB as an example of 'closed basin' without additional water sources and the implementation of economic instruments (reallocation, volumetric pricing, water rights markets, etc.) and technical strategies (water saving, improved water productivity and water efficiency). The implementation of WCSTs increases IE and affects farmers' decisions regarding the irrigated area, crop mix, and the widespread use of deficit irrigation (DI) techniques that may lead to a substantial increase in the productivity of irrigated agriculture (Expósito and Berbel 2016).

\section{Methodology.}

\subsection{Case study description.}

The Guadalquivir river is about $650 \mathrm{~km}$ long and has a basin area of over 57,527 $\mathrm{km}^{2}$, making it the most important river basin in southern Spain with a share of $23 \%$ of Spain's total irrigated land (CHG 2016). The GRB is representative of Mediterranean basins, where all available water resources are allocated to increasingly high levels of competing demand and the supply capacity has reached its maximum (Expósito and Berbel 2017a). The competitiveness of its irrigated agriculture, which is based on high-value crops, explains the remarkable expansion in irrigated areas and modernisation of irrigation.

Table 1 shows the evolution of the irrigated area and the supply capacity of the GRB in terms of the reservoir capacity (1950-2015) and proposes different stages in terms of the evolution of these two indicators. In the first stage (1950-1989), the irrigated area almost tripled mainly due to public investment in irrigated schemes supported by a significant increase in reservoir capacity (from 1,277 to $5,175 \mathrm{hm}^{3}$ ), which guaranteed water supply. The share of furrow irrigation is dominant in this period (Table 2). The second period (1989-2005) is characterised by intense investment in WCSTs (mainly dripirrigation schemes in irrigated olive groves and citrus orchards) financed both by public and private capital. According to the official figures as reported by regional government (CAP 2010, 2011), the total investment for Andalusia (where GRB constitutes $85 \%$ of the irrigated area of the region) was estimated at 1.54 billion EUR (with subsidies around 59\%). The intense expansion of irrigated agriculture during the period 1989-2005 was reflected in an average increase of 32,000 ha per year (well above the average increase in the previous period), while the reservoir capacity reached $7,500 \mathrm{hm}^{3}$, and increased at an average annual rate (145 $\mathrm{hm}^{3} /$ year) that was also higher than in the previous period. In this period, the GRB irrigated area reached 829,000 ha, which is close to the maximum irrigated area forecast at 890,000 ha as approved by the GRB Authority in the GRB Hydrological Plan (2015-2021), since additional supply is not economically feasible (CHG 2016). The last stage (2005-2012) is characterised by the slower growth of irrigated land (mainly drip-irrigated olive and citrus trees) and the construction of the last dams in the basin. In the current scenario, no supply increases are foreseen, and irrigated area expansion is subject to restrictive administrative authorisation. 


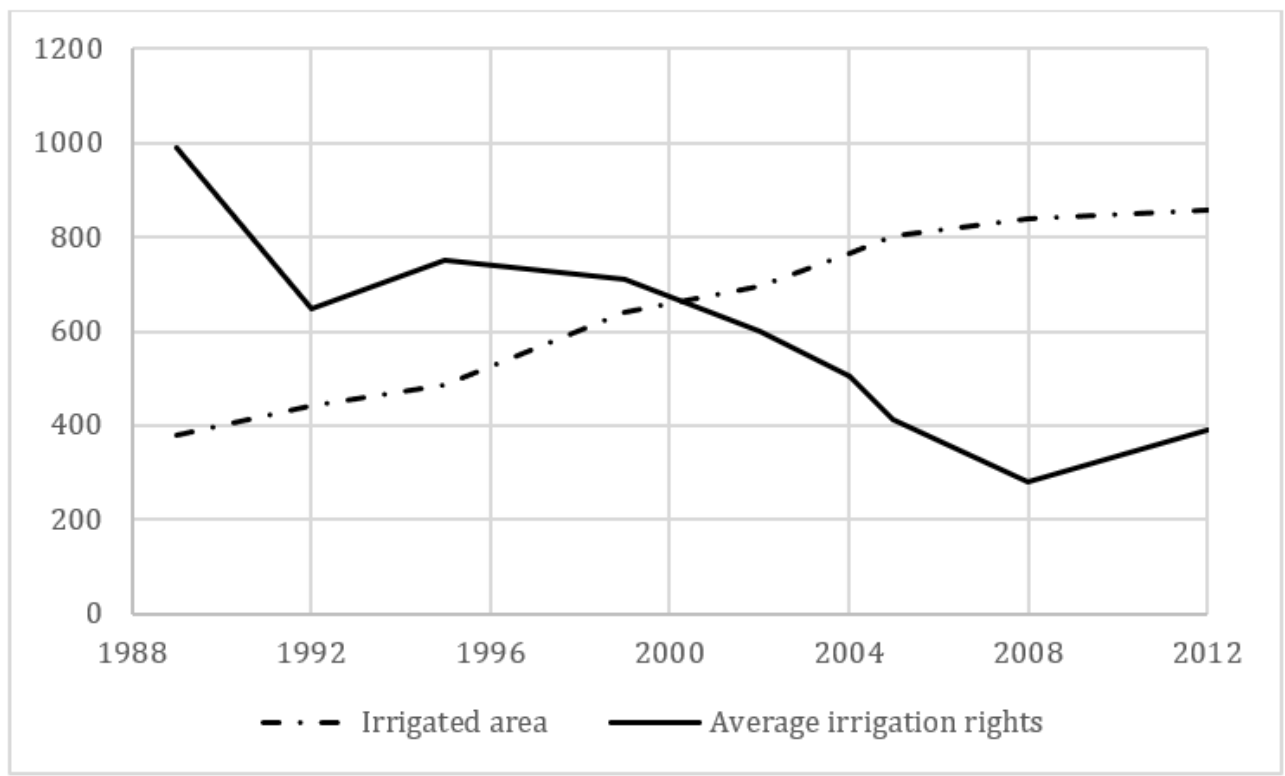

Figure 1. Average irrigation rights $(\mathrm{mm})$ and irrigated area (thousands of hectares).

Source: Authors' own based on data from MAGRAMA and CHG.

Against this background, demand management has become a crucial tool for the reduction of pressure on the resource in different socio-economic sectors, including that of agriculture (Corominas 2010). Additionally, the use of irrigation techniques of greater efficiency also plays a key role in achieving water-saving objectives.
The continuous increase in the irrigated area in the GRB has occurred mainly through the conversion of rain-fed olive groves into irrigated groves and the expansion of the area dedicated to irrigated citrus orchards (MAGRAMA 2015) and has been made possible through the implementation of WCSTs. Figure 1 shows this expansion of the irrigated area in the GRB during the period 1989-2012 and the evolution of

Table 1. Stages of irrigation in the GRB.

\begin{tabular}{llccccc}
\hline \multicolumn{1}{c}{ Stage } & & $\begin{array}{c}\text { Irrigated } \\
\text { hectares } \\
\text { (initial) }\end{array}$ & $\begin{array}{c}\text { Irrigated } \\
\text { hectares } \\
\text { (final) }\end{array}$ & $\begin{array}{c}\text { Reservoir } \\
\text { capacity } \\
\left(\mathrm{hm}^{3}\right)\end{array}$ & $\begin{array}{c}\Delta \text { Irrigation } \\
\text { (ha/year) }\end{array}$ & $\begin{array}{c}\Delta \text { Reservoir } \\
\left(\mathrm{hm}^{3} / \text { year }\right.\end{array}$ \\
\hline $1 \begin{array}{l}\text { Agronomic } \\
\text { development }\end{array}$ & $1950-1989$ & 114,229 & 317,139 & 5,175 & 5,205 & 100 \\
\hline $\begin{array}{l}\text { Area expansion } \\
\text { \& modernisation }\end{array}$ & $1989-2005$ & 317,139 & 829,943 & 7,500 & 32,050 & 145 \\
\hline $\begin{array}{l}\text { Area non- } \\
\text { expansion \& } \\
\text { modernisation }\end{array}$ & $2005-2012$ & 829,943 & 852,360 & 8,562 & 3,202 & 152 \\
\hline $4 \begin{array}{l}\text { Current \& Future } \\
\text { scenario }\end{array}$ & $2012-2027$ & 852,360 & 890,000 & 8,562 & 2,500 & 0 \\
\hline
\end{tabular}

Source: Authors' own. 
Table 2. Irrigation techniques (\% of irrigated land) and average IE in the GRB.

\begin{tabular}{ccccccc} 
& $1989^{1}$ & $1999^{2}$ & $2002^{2}$ & $2004^{2}$ & $2008^{3}$ & $2013^{4}$ \\
\hline Gravity & $61 \%$ & $45 \%$ & $40 \%$ & $38 \%$ & $22 \%$ & $19 \%$ \\
\hline Sprinkler & $27 \%$ & $20 \%$ & $22 \%$ & $17 \%$ & $12 \%$ & $11 \%$ \\
\hline Drip & $12 \%$ & $35 \%$ & $38 \%$ & $45 \%$ & $66 \%$ & $70 \%$ \\
\hline Average IE & 0.70 & 0.75 & 0.76 & 0.79 & 0.82 & 0.83 \\
\hline
\end{tabular}

Source: Authors' own based on ${ }^{1}$ Agricultural census; ${ }^{2}$ Irrigation census; ${ }^{3}$ Hydrological RB plan; 4 MAPAMA-ESCIRCE.

available irrigation water (i.e., water rights) per irrigated hectare. This rapid expansion of the irrigated area decelerates significantly from 2005 onwards, due to the declaration of an administrative moratorium on new irrigated areas in the main sub-basin (90\% of total basin area). The impact of this moratorium is reflected in the reduction of the average annual growth rate of irrigated areas, from $9 \%$ in the period $1989-2005$ to $0.8 \%$ in subsequent years and in the related reduction in the average water rights per hectare (as shown by the downward-sloping solid line in Figure 1) since resources cannot be increased and are distributed across a larger area.

In this scenario, farmers have adapted to this reduction in irrigation-water rights by: a) intensifying investment in WCSTs; b) changing the crop mix to maximise the economic value generated per irrigation unit; and c) expanding the irrigated area by distributing the water rights over a larger area with the use of deficit irrigation (DI) techniques facilitated by WCSTs. The intense investment in WCSTs has played a decisive role in the significant increase in irrigation water productivity in recent decades. The fact that the irrigated area in the basin doubled at the same time as a drastic reduction was introduced in the average irrigation rights per hectare can only be explained by the major investments made in WCSTs. Higher IE and a greater share of higher-value crops (mainly of olives and citrus trees) helped the basin to reach high efficiency levels in the use of irrigation water. Table 2 illustrates the continuous increase in drip-irrigated areas and the estimated average IE. Widespread high IE systems constitute a differential feature of GRB with respect to the rest of Spain (where drip irrigation represents barely $50 \%$ of all irrigated land).

Investment in WCSTs has also enabled significant changes in the composition of major crops cultivated in the basin. Farmers have tended to respond to the increasing water costs and resource scarcity by dedicating more land to the cultivation of crops of high added value that use irrigation water more efficiently, with olive and citrus crops being notable examples (Table 3). The average application of irrigation water in the 
Table 3. Evolution of the irrigated area (ha) for major crops in the GRB (1989-2015).

\begin{tabular}{|c|c|c|c|c|c|}
\hline Type & & 1989 & 2005 & 2012 & 2015 \\
\hline \multirow{2}{*}{ Cereal } & Rice & 38,698 & 36,092 & 35,180 & 35,180 \\
\hline & Corn & 23,000 & 46,404 & 17,668 & 19,690 \\
\hline \multirow{2}{*}{ Industrial } & Cotton & 30,000 & 77,020 & 55,302 & 61,908 \\
\hline & Sugar beet & 22,885 & 20,185 & 12,230 & 13,453 \\
\hline Citrus & Oranges & 13,274 & 22,578 & 38,013 & 41,822 \\
\hline \multirow{2}{*}{ Olives } & $\begin{array}{l}\text { Table } \\
\text { olives }\end{array}$ & 34,644 & 39,100 & 42,238 & 42,906 \\
\hline & $\begin{array}{l}\text { Oil-mill } \\
\text { olives }\end{array}$ & 39,358 & 380,930 & 433,080 & 439,922 \\
\hline
\end{tabular}

Source: Authors' own based on data from MAGRAMA and CHG.

basin fell by approximately $700 \mathrm{~m}^{3} / \mathrm{ha}$ between 2005 and 2015, which affected most of the crops but had a particularly marked impact on traditional olive groves, where the use of DI practices is more widespread. The consequence of generalized DI has been a continuous decline in the Average Relative Irrigation Supply (ARIS) ratios for major crops of the GRB in recent decades, especially in olive groves (Expósito and Berbel 2017a), as well as on a river basin scale (Lopez-Baldovin et al. 2006).

The expansion of olive and citrus crops over recent decades and the parallel decline in cereal and industrial crops is explained by the differences of irrigation water productivity. Table 4 shows irrigation water productivity (GVA per $\mathrm{m}^{3}$ ) and land productivity (GVA per hectare) for major irrigated crops in the GRB for the year 2015. The highest irrigation water productivity is achieved by olive and citrus crops, which have registered the largest increase in cultivated area over the analysed period (more than 60\% of the total irrigated area in the GRB). It is worth noting that increases in irrigation water productivity cannot be explained by an increase in crop prices, since prices of major crops in the GRB have decreased in real terms in the last two decades (Castillo et al. 2017), as reported in other

Table 4. Irrigation water and land productivities for major crops in the GRB (2015).

\begin{tabular}{cccc}
\multicolumn{2}{c}{ Type of crop } & $\begin{array}{c}\text { Land } \\
\text { productivity } \\
(\mathrm{EUR} / \mathrm{ha})\end{array}$ & $\begin{array}{c}\text { Irrigation water } \\
\text { productivity } \\
\left(\mathrm{EUR} / \mathrm{m}^{3}\right)\end{array}$ \\
\hline \multirow{2}{*}{ Cereal } & Rice & 2,482 & 0.23 \\
\cline { 2 - 4 } & Corn & 2,768 & 0.50 \\
\hline \multirow{2}{*}{ Industrial } & Cotton & 2,463 & 0.49 \\
\cline { 2 - 4 } & Sugar beet & 3,659 & 0.73 \\
\hline \multirow{2}{*}{ Citrus } & Oranges & 6,180 & 1.05 \\
\hline \multirow{2}{*}{ Olives } & Table olives & 1,755 & 1.17 \\
\cline { 2 - 4 } & Oil-mill olives & 2,500 & 1.66 \\
\hline
\end{tabular}

Source: Authors' own based on data from MAGRAMA and CHG. 


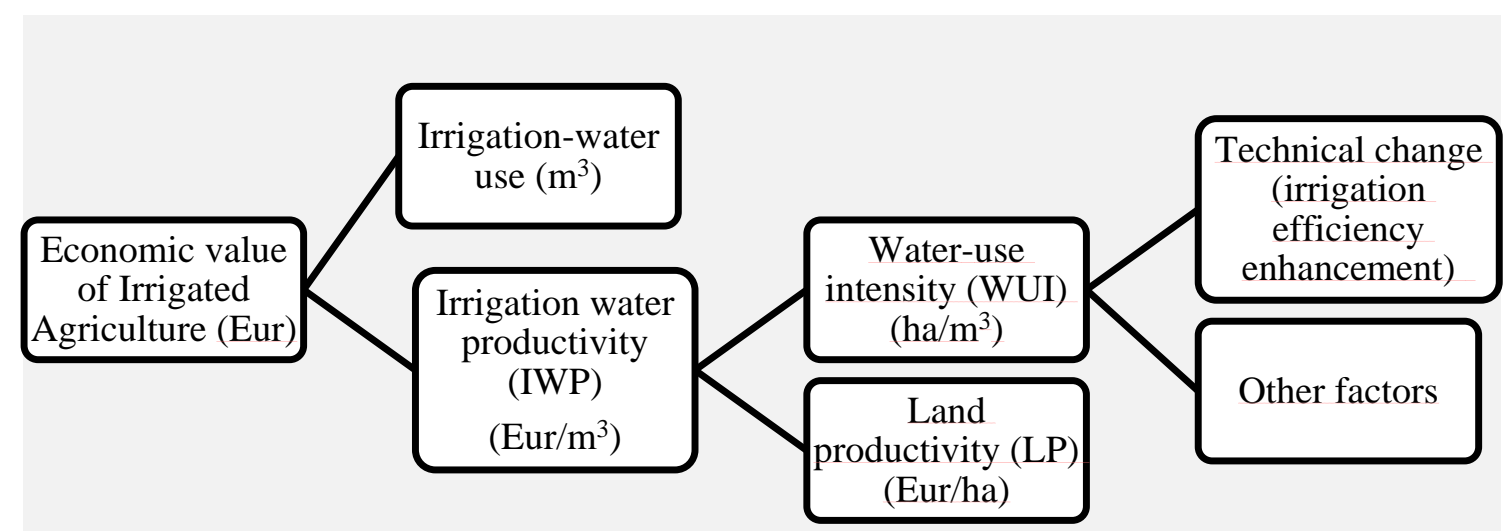

Mediterranean regions (Zingaro et al. 2017).

\subsection{Analytical framework.}

Irrigation water productivity takes irrigation as the production input to generate irrigated agriculture economic value. Young and Loomis (2014) argue that the most commonly used analytical frameworks for the determination of the economic value of irrigation include: 1) market price comparisons based on transaction prices among irrigation users; 2) residual-value methods at farm and crop levels; and 3) input/output methods based on production estimates of irrigated and rain-fed crops.

This paper examines the sources of change in irrigation water productivity estimated as the economic value (measured as GVA) generated by irrigated agriculture per irrigation unit. The estimation method is based on the assessment of land productivity (LP) (in terms of GVA/ha) and water-use intensity (WUI) (in terms of the ratio $\mathrm{ha} / \mathrm{m}^{3}$ ) ratios (Figure 2). Along these lines, the European Environmental Agency (EEA) cites the latter as a useful ratio for the analysis of resource productivity instead of the more frequently used inverse ratio of water productivity $\left(\mathrm{GVA} / \mathrm{m}^{3}\right.$ of irrigation water). Improvements in water-use intensity generally reflect technical advances in irrigation techniques (e.g., change from furrow to drip irrigation), but they may also be explained by other factors, such as the use of DI practices, which, in the case of oil-mill olive groves in the GRB, play a relatively important role.

Figure 2. Decomposition of the economic value of irrigated agriculture on a river basin scale.

Source: Authors' own.

Thus, in order to assess the trajectory followed by irrigation water productivity in the closure process of the GRB, as well as assessing its two components (Figure 2), we propose the decomposition of irrigation water productivity (IWP) given by the following expression:

$$
I W P=\frac{V_{j}}{I_{j}}=\frac{V_{j}}{A_{j}} \cdot \frac{A_{j}}{I_{j}}
$$

where: $V_{j}=$ GVA generated from irrigated agriculture on a river basin scale in year ' $\mathrm{j}$ ' (measured in euros); $\mathrm{A}_{\mathrm{j}}$ $=$ irrigated area in the river basin in year 'j' (measured in hectares); $I_{j}=$ total volume of irrigation water used in the 
river basin (measured in terms of allocated water rights in $\mathrm{hm}^{3}$ ).

The above equation can be summarized as:

$$
I W P=L P \cdot W U I
$$

where IWP $=\frac{V_{j}}{I_{j}}$ and $\mathrm{LP}=\frac{V_{j}}{A_{j}}$ is a measure of land productivity (GVA generation per hectare); and WUI $=\frac{A_{j}}{I_{j}}$ indicates water-use intensity (as a measure of resource-use intensity). In terms of variation rates, it can be simply represented as the sum of individual variation rates, as given by the following expression:

$$
\frac{\Delta I W P}{I W P}=\frac{\Delta L P}{L P}+\frac{\Delta W U I}{W U I}
$$

where the growth (variation) rate of irrigation water productivity can be expressed by the sum of the variation rate of land productivity (mainly driven by higher crop intensification) and the variation rate of water-use intensity (mainly driven by higher IE through technical change).

\section{Results.}

The estimated results are shown in Table 5. In the period 1989-2005, a remarkable expansion of irrigated agriculture occurred in the GRB, both in terms of GVA generated $(9.6 \%$ average annual growth rate) and irrigated area $(9.5 \%$ average annual growth rate, mainly due to the expansion of irrigated olive groves but also to that of other crops such as corn and cotton, as shown in Table 2). Although irrigation water used in the basin increases (from 2,533 to 3,176 $\mathrm{hm}^{3}$ ) due to the extraordinary development of irrigated agriculture (thanks to new reservoirs and groundwater exploitation), the average volume of irrigation water used per hectare falls by $59 \%$ in this period (as shown in Figure 1). Higher IE through WCST investment enabled the expansion of the irrigated area with reduced water rights per hectare and this explains the increase in water productivity in the period 1989-2005, rising from 0.29 to $0.60 \mathrm{EUR} / \mathrm{m}^{3}(4.4 \%$ average annual increase). As shown by the estimated average annual growth rates in both periods, the change in irrigation water productivity between 1989 and 2005 is almost entirely explained by an increase in water-use intensity which represents $99 \%$ of the

\begin{tabular}{|c|c|c|c|c|c|}
\hline & \multirow[b]{2}{*}{1989} & \multirow[b]{2}{*}{2005} & \multirow[b]{2}{*}{2012} & \multicolumn{2}{|c|}{$\begin{array}{l}\text { Average annual } \\
\text { growth rate }(\%)\end{array}$} \\
\hline & & & & $1989-2005$ & $2005-2012$ \\
\hline GVA irrigated agriculture (million EUR) & 746 & 1,899 & 2,171 & 9.66 & 2.05 \\
\hline Irrigated area (thousand ha) & 317 & 801 & 853 & 9.54 & 0.93 \\
\hline Irrigation water used $\left(\mathrm{hm}^{3}\right)$ & 2,533 & 3,176 & 3,336 & 1.58 & 0.72 \\
\hline $\begin{array}{l}\text { Land productivity (LP) } \\
\text { (EUR/ha) }\end{array}$ & 2,354 & 2,370 & 2,545 & 0.04 & 1.02 \\
\hline $\begin{array}{l}\text { Water-use intensity (WUI) } \\
\left(\mathrm{ha} / \mathrm{m}^{3}\right)\end{array}$ & 0.00012 & 0.00025 & 0.00027 & 4.38 & 0.20 \\
\hline $\begin{array}{l}\text { Irrigation water productivity (IWP) } \\
\left(\mathrm{EUR} / \mathrm{m}^{3}\right)\end{array}$ & $0.29^{(l)}$ & $0.60^{(1)}$ & $0.65^{(1)}$ & $4.43^{(2)}$ & $1.22^{(2)}$ \\
\hline
\end{tabular}

Table 5. Estimation and decomposition of irrigation water productivity in the GRB.

Note: (1) Following Eq. 2; (2) Following Eq. 3. Constant 2012 prices. Source: Authors' own. 
annual growth rate of irrigation water productivity in that period. To a much lesser extent, the growth in irrigation water productivity can be explained by the observed change in land productivity (crop intensification), which registered an average annual growth rate of only $0.04 \%$ ( $1 \%$ of the annual growth rate of irrigation water productivity).

Conversely, between 2005 and 2012, average annual growth rates of GVA and that of the irrigated area decrease sharply, as does that of the irrigation water used: average irrigation rights per hectare decrease by $20 \%$ to approximately $3,400 \mathrm{~m}^{3} /$ ha (Figure 1), since the irrigated area grows faster than irrigation supply $(1.5 \%$ vs. $0.7 \%$, respectively). Consequently, there is a significant slowdown in the expansion of the irrigated area in this period compared to the previous period, due to the moratorium on new irrigated areas in the main sub-basin of the GRB. It may be the case that the increase in the irrigation water productivity (from 0.60 to 0.65 $\mathrm{EUR} / \mathrm{m}^{3}$ in constant 2012 prices) observed in this period, shows the capacity of the GRB to maintain GVA values with a lower irrigation water use. Compared to the preceding period, in the 2005-2012 period, the crop intensification (as shown by the estimated growth rate of land productivity) plays a significantly more important role as a driver of irrigation water productivity. This is mainly due to the expansion of high-value crops with a more efficient use of irrigation water (e.g., olive and citrus crops, as shown in Tables 3 and 4), which is responsible for $84 \%$ of the estimated annual growth of irrigation water productivity between 2005 and 2012. Although the growth of water-use intensity still plays a major role in explaining the rise in irrigation water productivity in the period 20052012 (16\%), this factor has considerably less explanatory power than it did in the period 1989-2005. Indeed, the largest investments in modernising irrigation techniques in the GRB were made during that 'intense modernisation' phase (Table 1). This is in line with the evolution of the average basin IE estimated in Table 2, which shows a more rapid average efficiency increase in the period 1989-2005 than in the subsequent period (2005-2012). This is explained by the fact that almost all the new irrigated area in the first period consisted of irrigated olives with drip irrigation (rising from $12 \%$ in 1989 to around $60 \%$ in 2005).

\section{Discussion.}

The evolution of estimated irrigation water productivity shows that the capacity of the GRB for an increase in irrigation GVA tends to level out in terms of generated value per irrigation unit (as shown by the significant decrease in the estimated annual growth rates between the two analysed periods, from $6.4 \%$ to $1.2 \%$ ) Additionally, as a result of the marked expansion of irrigation agriculture in the basin, water resources have become the limiting production factor, in contrast with the traditional model that defines land as the limiting factor. Since the degree of modernisation and efficiency of irrigation techniques in the basin is already high, the ability of irrigated farming to continue generating greater GVA declines: a situation that we 
believe characterises the current closure of the basin.

Thus, and based on the analysis carried out in this study, the following results should be highlighted as characteristics of the closure process of the GRB and the evolution of irrigation water productivity: 1) growth rate of irrigation water productivity shows a decreasing trend, to the point where it halts as the river basin closure process occurs; 2) the growth of irrigation water productivity relies significantly on technical change (water-use intensity) during the initial stages, although this factor has less explanatory power as the river basin achieves higher IE levels through WCST implementation; 3 ) the use of alternative agronomic practices (mainly DI in irrigated olive groves) to increase wateruse intensity becomes a relevant driver for this indicator and consequently of irrigation water productivity as widespread drip irrigation and improved conveyance and distribution networks on a basin scale help to boost efficiency; 4) growth of land productivity, mainly driven by changes in crop mix towards high-value crops, plays a greater role in explaining the dynamic evolution of irrigation water productivity when the river basin approaches closure status and high IE has already been achieved.

An adequate characterisation of a river basin, as called for by the EU Water Framework Directive (WFD), requires information on the major economic drivers and pressures on a river basin scale. Such findings can be employed to develop economic analyses that help to efficiently allocate water resources and design appropriate incentives (e.g., policy measures in the form of pricing) for an efficient use of the resource, thereby contributing towards the WFD objectives (Berbel and Expósito 2018; Gomez-Limon and Martin-Ortega 2013). We believe that, given the relative importance of irrigated agriculture in terms of its water demand, the analysis of the determinants and dynamics of irrigation water productivity on a river basin scale can improve our understanding of the key economic drivers that influence demand for the resource and thus affect water status in a river basin.

The trajectory followed by irrigation water productivity in the GRB is similar to other water-scarce regions and basins, such as the Murray-Darling river basin (Grafton 2016) and the Jordan river basin (Molle et al. 2010). Those river basins have also followed a closure process, wherein all available water resources are currently allocated to farmers, other economic uses and environmental flows (Molle et al. 2007). The analysis of our case study has clearly revealed how the combination of technological innovations in irrigation has led to greater resource-use efficiency, which has been accompanied by an expansion of the irrigated area, especially the area dedicated to crops capable of generating higher levels of GVA per irrigation unit (i.e., olive, vegetable, and citrus crops). Furthermore, the observed intensification process towards highervalue crops and the increasing share of trees and permanent crops implies an increased risk under drought or extremeevent conditions in the GRB, which could have serious consequences for the sustainability of irrigation and river basin governance, as well as for the effectiveness of climate-change adaptation strategies (Escriva-Bou et al. 
2017). A similar trend towards an increase in irrigated trees per hectare has been noted by Medellín-Azuara et al. (2016) in their analysis of the changes induced by drought in California and by Molle (2017) in the northern regions of Morocco.

Although irrigated area expansion is restricted in the case of the GRB and water rights have been capped, higher IE achieved and widespread use of DI practices in high-productivity crops (i.e., olive, citrus) may still intensify demand pressures. In this context, the GRB Authority needs to enforce further policy controls to prevent additional irrigation demands that cannot be met with the already depleted resources. Furthermore, the need to reallocate water from low- to high-value uses without increasing water consumption (as generally occurred in the period 1989-2012) requires the use of reallocation instruments (Dinar et al. 1997) such as water pricing and water trading (water markets), which represent an effective way of reallocating irrigation water among different productive uses (including alternative crops) in order to guarantee distributional efficiency (Wheeler et al. 2014). Water trade, however, has not been fully implemented on a river basin scale (Palomo-Hierro et al. 2015) and operates mainly during drought periods. Nevertheless, economically efficient allocation across competing uses entails allocating water resources to the highestvalue use at any moment (and is thus dynamic in nature), which may include allocating resources to the environment. In this regard, the analysis of the evolution of irrigation water productivity offers an economic valuation of the benefit generated by irrigated agriculture as a competing use of the resource.

Water pricing may play a more limited role in managing irrigation water use by encouraging water conservation and promoting efficiency (EEA 2017) (Molle and Berkoff 2007). Nevertheless, the increasing value of water and the changes in water demand induced by DI and implementation of WCSTs also result in a more inelastic demand, which would limit the potential effectiveness of water pricing (Expósito and Berbel 2017b; de Fraiture and Perry 2002).

\section{Concluding remarks.}

The estimated evolution of irrigation water productivity in the case study of the GRB has illustrated the evolution of irrigation water productivity to be a consequence of farmers' responses to resource scarcity involving WCST implementation (technical change) and changes in the crop mix (crop intensification). As shown by the proposed analytical framework, the observed increase in water-use intensity has been the main driver of irrigation water productivity growth in the period 1989-2005. During the subsequent period (2005-2012), although water-use intensity has still increased, growth in land productivity has increased its capacity significantly to explain the growth of irrigation water productivity on a basin scale.

Future research should extend this analysis to other water-scarce regions, in an attempt to reveal similarities and differences in the adaptation processes, and in the socio-economic and environmental impacts of the various institutional and technological responses. The analysis of the economic 
implications of river basin closure processes may support sound policymaking and it can also help prevent the undesirable increase in irrigation water consumption that has arisen in certain regions where subsidies for WCST implementation have been granted.

We hope that this paper opens new avenues for research into the determinants of irrigation water productivity and their interactions with other factors and processes observed on a river basin scale. These findings regarding the evolution of economic variables, such as irrigation water productivity, combined with a greater understanding of irrigation governance in a context of river basin closure, may contribute towards advances in agricultural water management, particularly when embedded within an integrated water management approach, thereby leading to more sustainable irrigation in the future.

\section{Glossary}

ARIS: Average relative irrigation supply.

DI: Deficit irrigation.

GRB: Guadalquivir river basin.

GVA: Gross value added.

IE: Irrigation efficiency.

IWP: Irrigation water productivity.

LP: Land productivity.

WCSTs: Water conservation and saving technologies.

WUI: Water-use intensity.

Conflict of Interest: None.

Authors' contribution: Both authors

have contributed equally to this

research.

\section{References}

Berbel J, Expósito A (2018) Economic challenges in the EU Water Directive Framework reform and implementation. Eur Plan Stud 16(1): 20-34. https://doi.org/10.1080/09654313.2017.136 4353

Berbel J, Pedraza V, Giannoccaro G (2013) The trajectory towards basin closure of a European river: Guadalquivir. Int J River Basin Manag 11(1): 111-119. https://doi.org/10.1080/15715124.2013.768 625

CAP (2010) Inventario de regadíos 2008 y su evolución en la última década, Consejería de Agricultura y Pesca, Junta de Andalucía, Seville, Spain.

CAP (2011) Agenda del Regadío Andaluz H-2015, Consejería de Agricultura y Pesca, Junta de Andalucía, Seville, Spain.

CHG (2016) Plan Hidrológico de la Demarcación del Guadalquivir 2015-2021, R. D. 1/2016, Confederación Hidrográfica del Guadalquivir, Seville, Spain.

Comair GF. Gupta P, Ingenloff C, Shin G, McKinney DC (2013) Water resources management in the Jordan River Basin. Water Environ J 27(4): 495-504. https://doi.org/10.1111/j.1747-

6593.2012.00368.x

Corominas J (2010) Los nuevos Planes Hidrológicos de las Cuencas Andaluzas, Observatorio del Agua de la Fundación Botín, Madrid, Spain.

Doorenbos J, Kassam A (1979) Yield response to water. FAO Irrigation and Drainage Paper 33, Food and Agriculture Organization of the United Nations (FAO), Rome, Italy.

EC (2012) EU Blueprint to Safeguard Europe's Water Resources. COM (2012) 673 Final. European Commission, Brussels.

EEA (2009) Water resources across Europe. Confronting water scarcity and drought. Report No 2/2009. European Environment Agency, Publications Office of the European Union, Luxembourg. 
EEA (2017) Water management in Europe: price and non-price approaches to water conservation. European Environment Agency, Publications Office of the European Union, Luxembourg.

Escriva-Bou A, Pulido-Velazquez M, Pulido-Velazquez D (2017) Economic value of climate change adaptation strategies for water management in Spain's Jucar Basin. J Water Res Pl-ASCE 143(5). https://doi.org/10.1061/(ASCE)WR.19435452.0000735

Expósito A, Berbel J (2016) Microeconomics of deficit irrigation and subjective water response function for intensive olive groves. Water 8(6): 254. https://doi.org/10.3390/w8060254

Expósito A, Berbel J (2017a) Economic productivity of irrigation water and the closure of a river basin in Southern Spain. 10th World Congress of EWRA "Panta Rei" Athens, Greece, 5-9 July 2017.

Expósito A, Berbel J (2017b) Why is water pricing ineffective for deficit irrigation schemes? A case study in southern Spain. Water Resour Manag 31(3): 1047-1059. https://doi.org/10.1007/s11269-016-1563-8

Falkenmark M, Molden D (2008) Wake up to realities of river basin closure. Int J Water Resour D 24(2): 201-215. https://doi.org/10.1080/0790062070172357 0

de Fraiture C, Perry CJ (2007) Why is agricultural water demand irresponsive at low Price ranges? In: Molle F, Berkhoff J (ed) Irrigation water pricing: the gap between theory and practice. Wallingford (UK) and Colombo. CABI Publishing and International Water Management Institute, pp. 94-107.

Gómez-Limón C, Martín-Ortega J (2013) The economic analysis in the implementation of the Water Framework Directive in Spain. Int J River Basin Manag 11(3): 301-310. https://doi.org/10.1080/15715124.2013.823 977
Grafton RQ (2016) Editorial: Water reform and planning in the Murray-Darling Basin, Australia. Water Economics and Policy 03: 1702001. https://doi.org/10.1142/S2382624X170200 15

Klein KK, Bewer R, Ali MK, Kulshreshtha SN (2012) Estimating water use efficiencies for water management reform in Southern Alberta irrigated agriculture. Water Policy 14(6):

1015-32. https://doi.org/10.2166/wp.2012.151

López-Baldovin MJ, Gutiérrez-Martin C, Berbel, J (2006). Multicriteria and multiperiod programming for scenario analysis in Guadalquivir river irrigated farming. J Oper Res Soc 57(5): 499-509. https://doi.org/10.1057/palgrave.jors.26020 29

López-Gunn E, Mayor B, Dumont A (2012) Implications of the modernization of irrigation. In: De Stefano L, Llamas MR (ed) Water, Agriculture and the Environment in Spain: Can we square the circle? CRC Press, pp. 241-256.

MAGRAMA (2015) Informe sobre Regadíos en España ESYRCE. Ministerio de Agricultura, Alimentación y Medio Ambiente, Madrid, Spain.

Medellín-Azuara J, MacEwan D, Howitt RE, Sumner DA, Lund JR, Scheer J, Gailey R, Hart Q, Alexander ND, Arnold B (2016) Economic analysis of the 2016 California drought on agriculture. California Department of Food and Agriculture, UC Davis Center for Watershed Science, California, US.

Molle F (2017) Conflicting policies: Agricultural intensification vs. water conservation in Morocco. Working Paper, Institut de Recherche pour le Développement, UMR-G-Eau: Marseille, France.

Molle F, Berkoff J (2007) Water pricing in irrigation: mapping the debate in the light of experience. In: Molle $\mathrm{F}$, Berkoff $\mathrm{J}$ (ed) Irrigation Water Pricing: The Gap between 
Theory and Practice. Wallingford, UK: CAB International, pp. 21-93.

Molle F, Wester P, Hirsch P (2010) River basin closure: Processes, implications and responses. Agr Water Manage 97(4): 569577.

https://doi.org/10.1016/j.agwat.2009.01.004

Molle F, Wester P, Hirsch P, Jensen JR, Murray-Rust H, Paranjpye V, Pollard S, Van der Zaag P (2007) River basin development and management. In: Molden D (ed) Water for food, water for life: A comprehensive assessment of water management in agriculture. London: Earthscan and Colombo, International Water Management Institute, pp. 585-624.

Palomo-Hierro S, Gómez-Limón JA, Riesgo L (2015) Water markets in Spain: performance and challenges. Water 7(2): 652-678. https://doi.org/10.3390/w7020652

Perry C (2011) Accounting for water use: terminology and implications for saving water and increasing production. Agr Water Manage 98(12): 1840-46. https://doi.org/10.1016/j.agwat.2010.10.002

Randall A (1981) Property entitlements and pricing policies for a maturing water economy. Aust J Agr Econ 25(3): 195-220. https://doi.org/10.1111/j.1467-

8489.1981.tb00398.x

Steduto P, Hsiao TC, Raes D, Fereres E (2012) Crop yield response to water. Food and Agriculture Organization of the United Nations (FAO), Rome, Italy.

Wheeler SA, Loch A, Zuo A, Bjornlund $\mathrm{H}$ (2014) Reviewing the adoption and impact of water markets in the Murray Darling Basin, Australia. J Hydrol 518: 28-41. https://doi.org/10.1016/j.jhydrol.2013.09.01 9

Young RA, Loomis JB (2014). Determining the economic value of water: concepts and methods. Routledge, London, UK.

Zingaro D, Portoghese I, Giannoccaro G (2017). Modelling crop pattern changes and water resources exploitation: A case study. Water, 9(9): 685. https://doi.org/10.3390/w9090685 